\title{
10 health stories that mattered this week: Feb. 21-27
}

- The owner of a controversial Florida health spa where two Ontario First Nations girls sought natural treatments for leukemia was ordered by the state to stop practising medicine without a licence. According to the $C B C$, Florida's Department of Health says it has probable cause to believe that Brian Clement treated the girls with "unproven and possibly dangerous therapies" at his Hippocrates Health Institute in West Palm Beach. One of the girls, Makayla Sault, died in January.

- The Canadian College of Homeopathic Medicine came under fire for making false claims about the dangers of vaccines and touting homeopathic concoctions called nosodes as alternatives. Following an investigation by the Globe and Mail, the college has since removed or changed several social media posts regarding vaccines and nosodes.

- Ontario updated its sex-education curriculum to reflect new issues affecting student health, including consent, sexting, masturbation and cyberbullying. The new curriculum will also introduce some topics in earlier grades. For example, students will learn about puberty in Grade 4, rather than Grade 5, as was previously the case.

- Ontario announced a \$28-million investment to support mental health and addiction services, including a new registry to provide doctors, first responders and emergency depart- ments with updates on available inpatient mental health beds across the province. The investment will also support increased access to services such as supportive housing, peer-support groups and treatment programs.

- Public hearings into Bill 20, a controversial act to promote access to family medicine, began in Quebec. Health Minister Gaétan Barrette defended the legislation, which would require doctors to take on a minimum of 1000 patients or risk losing 30\% of their pay, noting that $60 \%$ of Quebec doctors work fewer than 25 weeks a year.

- The variant of the measles virus currently circulating in Ontario had not been previously reported to the World Health Organization, which keeps a database of more than 22000 slightly different sequences of the virus. According to the Globe and Mail, public health officials had hoped that analysis of the measles viruses in Toronto's 11 recent cases might shed light on where the outbreak originated.

- Nova Scotia Auditor General Michael Pickup warned that the province is risking its future finances by not setting aside enough money to pay for the health benefits it owes to public sector employees upon retirement. The unfunded liability related to these benefits has hit $\$ 1.1$ billion, a sum that will have to be paid through future taxes and other revenues, Pickup said.
- Health Canada warned that tattoo removal gels and creams are linked to risks of scarring and skin irritation. These products may be applied topically or injected into the skin. The regulator received four separate reports of reactions related to tattoo removal products in the fall of 2014. In November 2014, the Collège des médecins du Québec formed a committee to regulate tattoo removal in the province after a Radio-Canada investigation uncovered 18 women who had suffered second-degree burns.

- Nova Scotia's government fired Arbitrator James Dorsey for failing to determine which unions will represent each of the province's four new bargaining units for health workers. As of Feb. 20, Dorsey had only clearly assigned the health care unit to the Nova Scotia Government and General Employees Union. The government will introduce legislation to determine which unions will represent the remaining three units of nurses, clerical and support workers.

- A satellite image of Newmarket Health Centre in Ontario went viral when newspapers in the United Kingdom pointed out its "uncanny resemblance to a spreadeagled man - complete with swinging manhood," as an Express article put it. — Lauren Vogel, CMAJ

CMAJ 2015. DOI:10.1503/cmaj.109-5009 